\title{
TASKS AND ROLE OF THE MECHANISM OF LEGAL PROTECTION OF INTELLECTUAL PROPERTY IN THE FUNCTIONING OF LEGAL RELATIONS IN THIS FIELD
}

Key words: protection of intellectual property; legal requirements; blanket disposition; property right.

ABSTRACT: The article is devoted to the coverage of the issue of criminal - legal protection of intellectual property at the present stage of state development.

Some issues of optimization of the ratio of criminal - legal and civil - legal protection of intellectual property, the issue of differentiation of criminal - legal protection of personal non-property and / or property rights of intellectual property to literary, artistic and other work (copyright) and personal non-property and / or property intellectual property rights for performance, phonogram, videogram and program (transfer) of broadcasting organization (related rights).

Unambiguous interpretation, logical wording in determining the signs and boundaries of socially dangerous acts and a clear relationship with other legal norms inevitably affect the correctness of law enforcement, provided that the legal constructions cover legal relations enshrined in the form of criminal offenses, delimiting criminal behavior from other actions and inaction .

However, the effectiveness of the mechanism and legal effectiveness of criminal - legal protection of intellectual property, the quality of the relevant criminal - legal prohibitions and their qualified and active application should be recognized as more significant in terms of functional purpose and impact on legal relations.

Thus, of course, the process of combating crimes against intellectual property directly depends on the degree of effectiveness of law enforcement agencies, both international law and

1 Graduate Student at the Faculty of Law, National Aviation University, stankevichyuriy@gmail.com; ORCID: orcid.org/0000-0003-2695-8834. 
legislation of Ukraine, as well as methods and techniques of intellectual property protection, which also contributes to the modern development of civil law, criminal law and procedural institutions of regulation and protection of intellectual property rights in view of the dynamics of such crimes, their type of affiliation, as well as persons who may be involved in their commission.

At the same time, there is no doubt that even perfect criminal law prohibitions cannot completely replace the professionalism of a law enforcer, his technical equipment, his knowledge of regulatory legislation and high-quality investigative and operational-investigative activities.

\section{INTRODUCTION}

The relevance of thematic scientific developments in the field of criminal - legal protection of intellectual property at the present stage of development of the state is certainly beyond doubt. With reference to the adopted regulations of the World Intellectual Property Organization, the XXI century is the century of intellectual economy, information society, where intellectual property is the driving force, resulting in innovative progress. The globalization of the economy, the development of science and technology, the processes of informatization of social relations determine the growth of socio - economic role and the importance of the results of intellectual activity, which necessitates the improvement of its legal protection (Konventsiia, 1967).

International regulation in the field of intellectual property is carried out in accordance with the agreements implemented by Ukraine, adopted by the World Intellectual Property Organization, which establishes mandatory for all member countries standards of protection and enforcement of intellectual property rights. In particular, the Agreement on TradeRelated Aspects of Intellectual Property Rights, the Berne Convention for the Protection of Literary and Artistic Works of 1886, the World Copyright Convention of 1952, the Paris Convention for the Protection of Industrial Property of 1883, the Madrid Agreement on the International Registration of Marks of 1891, the Hague international registration of industrial designs in 1925 and others (Doris, 2007).

The provisions of the Agreement on Trade-Related Aspects of Intellectual Property Rights (TRIPS) oblige Member States to criminalize 
intentional trademark infringement or copyright infringement on a commercial scale, allowing the criminalization of other infringements of intellectual property rights, especially when committed intentionally and on a commercial scale (Uhoda, 1994), and the provisions of the 2001 Council of Europe Convention on Cybercrime oblige member states to criminalize copyright and related rights infringements committed intentionally, on a commercial scale and using computer systems (Konventsiia, 2001).

Taking into account the challenges of society, the legislator enshrines criminal liability in the Criminal Code of Ukraine for committing a number of criminal offenses in the field of intellectual property, as the most severe type of state coercion, which is caused by modern intensive development of information society and modern legal relations between their subjects.

Analyzing the latest research, a thorough and significant impact on the development of legal science in this area made scientists P.P. Andrushkom, P.S. Berzin, VD Gulkevich, MI Melnik, S.Ya. Likhovoy, A.S. Nersesyan, VB Kharchenko and other scientists. However, in their scientific works there are many contradictions regarding the legal nature of the subject and object of legal protection.

\section{THE PURPOSE}

The purpose of the scientific article and research task is to highlight the problems of criminal - legal protection of intellectual property, partly through the prism of analysis of measures to combat crime in intellectual property in foreign countries, the formation of a scientifically sound approach to understanding the mechanism of such criminal protection, its functioning and legal influence on legal relations in this area. The article uses general scientific methods that are used at the theoretical level of research (induction, deduction, systems approach); as well as those used at the theoretical and empirical levels of research (formalization, abstraction, analysis and synthesis, systematization, generalization, modeling). 


\section{PROBLEMS OF DETERMINING THE SUBJECT OF CRIMINAL ENCROACHMENT ON INTELLECTUAL PROPERTY}

Undoubtedly, additional research requires questions about the optimization of the ratio of criminal - legal and civil - legal protection of intellectual property, the question of differentiation of criminal - legal protection of personal non-property and / or intellectual property rights to literary, artistic and other work (copyright) and personal non-property and / or property rights of intellectual property for performance, phonogram, videogram and program (transfer) of broadcasting organization (related rights).

However, as components of the subject of criminal encroachment, personal intangible intellectual property rights are inviolable and inalienable from their subject, are not transferred to other persons and are not inherited, and, as a general rule, are not recognized as objects of civil circulation, but socially - dangerous influence on them by all means takes place and on the value and consequences is not less dangerous. Such rights are legally recognized as the right of authorship, the right to assign a creative result its name or special title, the right to publish a work under its own name, under a pseudonym, the right to inviolability of the work, enshrined in Article 438 of the Civil Code and Article 14 law and related rights".

It should be emphasized that the functioning of such legal requirements plays one of the most important roles in law enforcement and legal protection of intellectual property.

The division of socially dangerous infringements of copyright and related rights into infringement of personal non-property rights and infringement of property rights is conditional. Even some scholars divide copyright infringement into three categories: infringement of personal non-property rights, including plagiarism, infringement of the author's property rights to the work, and mixed infringement of copyright (Dzera, 2005).

The provisions of current civil law establish that intellectual property rights are inviolable. No one may be deprived of intellectual property rights or restricted in their exercise, except in cases provided by law. At 
the same time, given the range of problems that currently exist and need to be addressed urgently in this area, Ukraine has been mentioned annually in the report since 1998 as a country where the level of protection of intellectual property rights is considered unsatisfactory. In 2013, Ukraine was assigned to the worst of the proposed categories of "priority foreign country" - a country with a significant market for counterfeit IT products.

According to The Special 301 Report of April 29, 2020 of the US Trade Representation, Ukraine remains on the list of priority observations, ie in the list of countries that do not provide protection of intellectual property rights, which is related to the following issues:

(1) unfair, non-transparent management of the system of collective management organizations responsible for the collection and distribution of royalties to rightholders;

(2) widespread use of unlicensed software by Ukrainian government agencies;

(3) failure to implement effective means to combat large-scale copyright infringement on the Internet.

In Ukraine during 2019, according to the statistics of the Prosecutor General's Office of Ukraine, 148 criminal offenses under Art. 176 of the Criminal Code of Ukraine. Compared to 2018, their number increased by 17.5\% (in 2018 - 126). Criminal offenses under Art. 229 of the Criminal Code of Ukraine, 62 were registered in 2019. This is $44.1 \%$ less than in 2018 (in 2018 - 111).

According to the Report of the courts of first instance on the consideration of materials of criminal proceedings for 2019 in Ukraine, the number of proceedings pending before the courts under Article 176 of the Criminal Code of Ukraine is 43, of which 19 were received in 2019. In 2019,15 proceedings were considered, with a verdict -9 (of which 2 - for conciliation and 2 - a guilty plea), 6 - with the closure of the proceedings. The number of persons in cases with completed proceedings is 15 , of which 7 were convicted, 2 were acquitted and 6 in respect of which the criminal proceedings were closed (Taran, 2020). 


\section{FACTORS OF DEPENDENCE OF LOCATION OF CRIMINAL - LEGAL NORMS IN THE FIELD OF INTELLECTUAL PROPERTY}

From the point of view of the object of the crime, its variety and features of characteristics, the location in the legal system of legal norms that regulate legal relations on criminal - legal protection of intellectual property depends (Dzera, 2005).

Thus, in comparison with the legislation of Ukraine on criminal offenses, separate sections on crimes against intellectual property are provided by the criminal legislation of Bulgaria, Estonia, Spain, Lithuania, Mexico, Peru, Finland. In some countries, criminal liability for crimes against intellectual property rights is provided by special legislation, namely: in France - the Intellectual Property Code, in Germany - the Law on Protection of Copyright and Related Rights, the Law on Protection of Industrial Designs, the Law on Protection of Trademarks and others designations, the New Plant Variety Protection Act and the Semiconductor Protection Act, in Portugal the Industrial Property Code, in Norway the Trademark Act, the Plant Breeders' Rights Act and the Copyright, Research and Artistic Rights Act, in Switzerland - the Law on Copyright and Related Rights, the Law on Patents for Inventions, the Law on the Protection of New Varieties of Plants.

In the United States, the legal norms that provide criminal protection of copyright and related rights are contained in a separate section of the US Code of Copyright "Yu.Truntsevskyi, 2007". The following dispositions of criminal offenses in the field of protection of copyright and related rights, protection of trademark rights and trade secrets have been identified.

According to Dudorov OO, the location of criminal - legal prohibitions depends on the classification of intellectual property rights to creative (literary and artistic works, utility models, plant varieties, etc.) or economic (means of individualization of participants in civil turnover, goods and services, trade secret), and depending on in what sphere of society certain intellectual property objects are used (Dudorov, 2012).

In the scientific works of such scientists as P.P. Andrushka, P.S. Berzina and others, the opinion is based on the connection and commonality of 
the generic object of the relevant group of crimes, as a set of relations on the results of intellectual, creative activity, means of individualization and unfair competition, separation in the Special Part of the Criminal Code of Ukraine. Crimes against intellectual property" or another similar name (Berzin, 2005).

This also corresponds to a unified understanding of intellectual property in the 1967 WIPO Convention and the need to implement the idea of intellectual property as a single single-object object of criminal law protection and the need for its unification (Tytov, 2013).

The socially significant role of socially dangerous (criminal) influence on legal relations in the field of intellectual property is that the consequences of committing crimes of this category violate the rights to the results of intellectual activity; right holders of intellectual property are deprived of the opportunity to receive income (lost profits), which would be obtained in ideal market conditions and, as a result, reduces the desire for further creative activity, reduces investment activity; the creator, having spent financial and intellectual resources to create an intellectual product, does not receive the expected profit from its commercial use; the budget also does not receive taxes and fees from the legal use of intellectual property (Dudorov, 2015).

Analyzing the case law according to the electronic database of the Unified State Register of Judgments for the period from 01.01.2020 to July 2021 , most convictions relate to individual violations that are "artificially detected" by the National Police or the Security Service of Ukraine solely to formally improve performance at the initiative and assistance to representatives of victims, within the framework of criminal proceedings in the form of private prosecution, ie in proceedings that can be initiated by the investigator, coroner, prosecutor only on the basis of the victim's statement on criminal offenses.

In this case, the offender, as a rule, in such cases admits guilt and enters into an agreement with law enforcement agencies and the victim, as it takes into account the ability and interest of the victim to establish the exact amount of damage.

For example, criminal prosecution, as a copyright, only at the request of the person whose rights have been violated (private prosecution) is also 
provided by the legislation of the Republic of Austria and the Kingdom of Denmark.

However, under the law of the Kingdom of Denmark, a criminal case against a person who has infringed the rights of the author or owner of property rights may be instituted by public authorities only in cases where such a violation may harm the cultural interests of the population.

It is necessary to point out such characteristics of crimes as grounds for criminal liability for infringements in the field of intellectual property, such as committing such offenses for commercial purposes without the permission of the owner, significant counterfeit volumes, wide range of public access to counterfeit items (Demidovich, 2012).

For example, the laws of some countries that emphasize the property nature of crimes against intellectual property qualify them as crimes against property. Thus, the Albanian Criminal Code considers the publication of another's work of literature, art, music or science under its own name and the reproduction or use of such work without the consent of the author with the violation of property rights as a form of fraud. In countries such as Bolivia, Georgia, Kazakhstan, Hungary, and Croatia, infringements of intellectual property rights (at least some of these encroachments) are also criminal offenses against property. The same approach is implemented in the Criminal Code of Spain, where Chapter 11 "On crimes related to intellectual and industrial property, market and consumers" is contained in Chapter XIII "Crimes against property and socio-economic order" of Book II "Crimes and Punishment" of this Code.

This is due to the fact that the same object of intellectual property rights, embodied in a tangible form, can be used repeatedly and each tangible medium can bring a certain income (profit) and become the object of ownership of an individual entity.

However, at the same time, intellectual non-property rights contain legal possibilities, so to speak, being the "right of abstract property", to receive material benefits from the results of intellectual creativity, and therefore, subject to regulations of civil law, in fact, may be subject criminal encroachments on property, in the sense of material things. 
Thus, often in criminal law practice there are cases of seizure of corporate rights of business entities in order to obtain legal and administrative control over individually identified property.

In this case, the position of S.Ya. Likhova, who recognizing property as a generic concept, which, in turn, is divided into two types - property (property) and intellectual property, substantiated the idea of changing the location of the rules on liability for crimes against intellectual property - acts under Articles 176, 177, 229, 231, 232, 232-1 of the Criminal Code of Ukraine, to Section VI of the Special Part of the Criminal Code of Ukraine "Crimes against Property" (Lykhova, 2006).

However, it is necessary to take into account the provisions of civil law that the object of intellectual property rights can only be an intangible object, ie the result of intellectual, creative activity. But not every result of such activity is recognized as an object of intellectual property rights, but only one that meets the requirements of the Central Committee of Ukraine and other laws of Ukraine on intellectual property. The results of intellectual, creative activity, which for one reason or another have not become the object of protection of intellectual property rights, may be recognized as objects of civil law, but not intellectual property rights.

At the same time, intellectual property rights are personal non-property intellectual property rights and (or) property intellectual property rights, the content of which in relation to certain objects of intellectual property rights is determined by the Central Committee of Ukraine and other laws. Personal intangible intellectual property rights do not depend on intellectual property rights (Dzera, 2005).

Thus, taking into account the object of criminal encroachment, it is possible to single out victims of socially dangerous acts, which can be the owner of the object of intellectual property rights, the author, creator, and the owner of the material carrier (thing) of intellectual property.

In the search for solutions, some scholars have suggested, given the dual legal nature, to ensure the harmonization of sanctions for crimes against property and crimes against intellectual property (Naumov, 2004). 


\section{WAYS TO OPTIMIZE LAWMAKING OF THE INSTITUTE OF LEGAL PROTECTION OF INTELLECTUAL PROPERTY AND THEIR RELATIONSHIP WITH THE LAW ENFORCEMENT OF LEGAL STRUCTURES}

At the same time, the effectiveness of the mechanism and legal effectiveness of criminal - legal protection of intellectual property, the quality of the relevant criminal - legal prohibitions and their qualified and active application should be recognized as more significant in terms of functional purpose and impact on legal relations.

At the same time, steps seem important not only to improve the criminal law on liability for criminal offenses against intellectual property, but also the functional, fundamental and political role and duty of state institutions to implement the relevant legal requirements.

It is appropriate to pay attention to the need to strengthen the procedural cooperation of law enforcement agencies of different countries, providers of organizations and institutions, including international, transnational, increase the efficiency of law enforcement agencies to create a common methodology for determining the amount of material damage. introduction of effective monitoring of Darknet black markets, owners of Internet resources (content) and increasing the responsibility of hosting owners.

Unambiguous interpretation, logical wording in determining the signs and boundaries of socially dangerous acts and a clear relationship with other legal norms will inevitably affect the correctness of law enforcement, provided that the legal constructions cover legal relations in the form of criminal offenses, delimitation of criminal behavior from other acts and without action individuals (Nersesian, 2010).

At the same time, excessive detailing of the composition of criminal offenses can have a negative impact on the legal qualification of the relevant acts and creates the risk of an objective impossibility to comprehensively cover their full range.

Given the blanket nature of legal norms that determine criminal liability for crimes against intellectual property, the need for additional analysis of civil law, determining the circumstances of infringement of 
intellectual property rights, calculation and determination of material damage, its nature and conditions of causation, causal links. language complicates the process not only of law enforcement and legal interpretation, but also, given the professional qualifications, limited resources, even the desire and ability to be prosecuted for violations in this area.

Such a legal position on improving the dispositions of criminal law norms as reducing the level of blanketing of dispositions in the articles of the Special Part of the Criminal Code of Ukraine seems to be sound, as the blanket method of presenting features of criminal offenses should be used only where such features are described. relevant field, law enforcement practice, experience of foreign countries is impossible and impractical (Iaremko, 2010).

Also interesting is the scientific point of view on the gradual formation of a separate institution of criminal law "Crimes against intellectual property" as required by criminal law methods of intellectual property protection (Novikov, 2015)

Thus, the subject of encroachment related to intellectual property, among other things, has such common features as confidentiality, confidentiality or, conversely, its dynamic circulation, the combination of intellectual property market demand and supply of intellectual property, professionalism intellectual work in basic and applied sciences, application of the latest technologies, utility models, industrial designs, scientific discoveries, innovation proposals.

Those socially significant legal relations, the violation of which is the most socially dangerous in the sense of harmful consequences, require the establishment of criminal - legal prohibitions.

Scientifically substantiated detailing of criminal law norms determines the basic law - making uniform normative features, which should fully and comprehensively cover the scope and possibilities of behavior in respect of which criminal liability has been established.

As a general rule, criminal offenses in the field of intellectual property, socially dangerous consequences of which are a mandatory feature of their composition, ie enshrined in the disposition as crimes with a material component, which recognizes the damage in material terms. 
The material composition of the crime for attribution of authorship, as in the Criminal Code of Ukraine, is enshrined in the criminal codes of Armenia, Azerbaijan, Turkmenistan, Kazakhstan.

At the same time, the objective side of the composition of criminal offenses of this category undoubtedly contains an understanding of the infliction of such damage in a qualitative sense, namely the type and nature of the violation of non-property rights of the victim.

However, there is a reference to causing significant damage without specifying it and explaining what the legislator means by it.

In view of the above, under the legislation of many European countries (Austria, Denmark, Italy, Germany, Switzerland and a number of other countries) criminal - encroachments on intellectual property are recognized as crimes with a formal composition.

Recently, in some countries (for example, Estonia, Spain, Lithuania, USA) criminalized the production and distribution of devices and programs for the removal of intellectual property protection. However, substantially illegal actions to circumvent or neutralize technical devices or technological developments in the protection of copyright and related rights are nothing but preparation for a criminal offense under the relevant crime of this category.

As world practice shows, the tendencies of increasing criminal liability for infringement of intellectual property rights, as in the USA, Japan, China, are also present in the development of European Union legislation both at the national and international levels.

For example, the introduction of severe sanctions for copyright infringement on the Internet in France, the adoption of the so-called "Nadopi" law, which provided for the forced disconnection of users from the Internet and the responsibility of providers for failure to take timely preventive measures to source intellectual property (Kachurovskyi, 2015).

\section{CONCLUSIONS}

Thus, of course, the process of combating crimes against intellectual property directly depends on the degree of effectiveness of law enforce- 
ment agencies, both international law and legislation of Ukraine, as well as methods and techniques of intellectual property protection, which also contributes to the modern development of civil law, criminal law and procedural institutions of regulation and protection of intellectual property rights in view of the dynamics of such crimes, their type of affiliation, as well as the characteristics of persons who may be involved in their commission.

Thus, in order to improve law enforcement and overcome "intellectual crime" it is necessary to involve not only in the process of improving the legal structures of criminal acts, but also in the implementation of professional functions of the state apparatus, qualified professionals in the field of intellectual property.

There is no doubt that even perfect criminal law prohibitions cannot completely replace the professionalism of a law enforcer, his technical equipment, his knowledge of regulatory legislation and quality investigative and operational - investigative activities.

\section{BIBLIOGRAPHY:}

Berzin, P.S. (2005). Nezakonne vikoristannya zasobiv individualizaciï uchasnikiv gospodars'kogo oborotu, tovariv ta poslug: analiz skladiv zlochinu, peredbachenogo st. 229 KK Ukraïni [Illegal use of means of individualization of participants of economic turnover, the goods and services: the analysis of structures of the crime provided by Art. 229 of the Criminal Code of Ukraine: monograph]. Kiev: Atika.

Dzera, O.V. (2005). Naukovo - praktichnij komentar Civil'nogo kodeksu Ukraïni: u 2 tomah / za red. O.V. Dzeri, N.S. Kuznecovoï, V.V. Lucya [Scientific and practical commentary on the Civil Code of Ukraine: in 2 volumes / ed. O.B. Dzeri, N.S. Kuznetsova, VV Lucy]. Kiev: YUrinkom Inter.

Demidovich, Є.G., Prohorov-Lukin, G.V. (2012). Zahist avtors'kogo prava i sumizhnih prav u kriminal'nomu zakonodavstvi deyakih evropejs'kih kraïn [Protection of copyright and related rights in the criminal law of some European countries]. Pidpryiemnytstvo, hospodarstvo i pravo № 12. Khmelnytsk: YUrinkom.

Lonh, D., Rei, P., Zharov, V.O., Sheveleva, T.M., Drobiazko, V.S. (2007). Zakhyst prav intelektualnoi vlasnosti: normy mizhnarodnoho i natsionalnoho zakonodavstva ta 
yikh pravozastosuvannia [Protection of intellectual property rights: norms of international and national legislation and their law enforcement]. Kiev: «K.I.C.».

Dudorov, O.O. (2012). Komertsiina taiemnytsia pid zakhystom kryminalnoho zakonu: problemy i perspektyvy [Commercial secret under the protection of criminal law: problems and prospects. Osnovni napriamy rozvytku kryminalnoho prava ta shliakhy vdoskonalennia zakonodavstva Ukrainy pro kryminalnu vidpovidalnist: materialy mizhnar. nauk.-prakt. konf., 11-12 zhovtnia 2012 r. / redkol.: V.Ya. Tatsii (holov. red.), V.I. Borysov (zast. holov. red.) ta in. Kharkiv: Pravo.

Dudorov, O.O. (2015). Problemy kryminalno - pravovoi okhorony intelektualnoi vlasnosti v Ukraini [Problems of criminal - legal protection of intellectual property in Ukraine]. Visnyk Luhanskoho derzhavnoho universytetu vnutrishnikh sprav imeni E.O. Didorenka. Luhansk: YUr journal.

Kachurovskyi, V. (2015). Kryminalna vidpovidalnist za porushennia osobystykh nemainovykh prav avtora [Criminal liability for violation of personal non-property rights of the author]. Natsionalnyi yurydychnyi zhurnal: teoriia i praktyka, liutyi 2015. Kiev: Natsionalna akademiia pravovykh nauk Ukrainy.

Konventsiia pro zasnuvannia Vsesvitnoi orhanizatsii intelektualnoi vlasnosti vid 14 lypnia 1967 roku [Convention on the Establishment of the World Intellectual Property Organization of July 14, 1967].

Konventsiia Rady Yevropy pro kiberzlochynnist vid 23.11.2001 [Council of Europe Convention on Cybercrime of 23 November 2001].

Lykhova, S.Ya. (2006). Zlochyny proty hromadianskykh, politychnykh ta sotsialnykh prav i svobod liudyny i hromadianyna za Kryminalnym kodeksom Ukrainy (teoretykopravove doslidzhennia) [Crimes against civil, political and social rights and freedoms of man and citizen under the Criminal Code of Ukraine (theoretical and legal research)]. Kiïv: Vydavnycho-polihrafichnyi tsentr «Kyivskyi universytet».

Lykhova, S.Ya. (2006). Zlochyny u sferi realizatsii hromadianskykh, politychnykh ta sotsialnykh prav i svobod liudyny i hromadianyna (rozdil V Osoblyvoi chastyny KK Ukrainy) [Crimes in the sphere of realization of civil, political and social rights and freedoms of a person and a citizen (Section V of the Special Part of the Criminal Code of Ukraine)]. Kiev: Vydavnycho-polihrafichnyi tsentr «Kyivskyi universytet».

Naumov, A.V. (2004). Rossyiskoe uholovnoe pravo. Kurs lektsyi. V dvukh tomakh. Osobennaia chast [Russian criminal law. Course of lectures. In two volumes. Special part]. Moskva: Yurydycheskaia lyteratura.

Nersesian, A.S. (2010). Kryminalno-pravova okhorona prav intelektualnoi vlasnosti [Criminal protection of intellectual property rights]. Khmelnytskyi: Vydavnytstvo Khmelnytskoho universytetu upravlinnia ta prava. 
Novikov, M.M. (2015). Do systemy pravovykh metodiv borotby zi zlochynnistiu u sferi intelektualnoi vlasnosti [To the system of legal methods of combating crime in the field of intellectual property]. Kiev: Pravo i suspilstvo.

Taran, O.V., Havlovskyi V.D. (2020). Zakhyst intelektualnoi vlasnosti v merezhi Internet [Protection of intellectual property on the Internet]. Kiev: Information and Law.

Truntsevskyi, Yu, Bondarev, M. (2007). Prestuplenyia protyv yntellektualnoi sobstvennosty [Intellectual property crimes]. Moskva: Pravo.

Tytov, S.N. (2013). Uholovno-pravovoe obespechenye okhrant yntellektualnoi sobstvennosty [Criminal law support for the protection of intellectual property]. Moskva: Obshchestvo y pravo.

18. Uhoda pro torhovelni aspekty prav intelektualnoi vlasnosti iak Dodatok do Uhody pro zasnuvannia Svitovoi orhanizatsii torhivli vid 15.04.1994 [Agreement on traderelated aspects of intellectual property rights in addition to the Agreement establishing the World Trade Organization from 15.04.1994].

Iaremko, H.Z. (2010). Blanketni dyspozytsii v stattiakh Osoblyvoi chastyny kryminalnoho kodeksu Ukrainy [Blanket dispositions in articles of the Special part of the criminal code of Ukraine]. Lviv: Lvivskyi derzhavnyi universytet vnutrishnikh sprav. 